\title{
Microbiological and physicochemical assessments of groundwater quality at Punjab, Pakistan
}

\author{
Ammara Hassan ${ }^{1 *}$ and M. Nawaz ${ }^{2}$ \\ ${ }^{1}$ Pakistan Council of Scientific and Industrial Research, Lahore, Pakistan. \\ ${ }^{2}$ College of Earth and Environmental Sciences, University of the Punjab, Lahore, Pakistan.
}

Received 10 February, 2014; Accepted 23 June, 2014

\begin{abstract}
The assessment of groundwater is essential for the estimation of suitability of water for safe use. An attempt has been made to study the groundwater at the district level of Punjab, Pakistan. These samples were analyzed for various water quality parameters like $\mathrm{pH}$, color, odor, conductance, total suspended solids, trace metals ( $\mathrm{Fe}, \mathrm{Cu}, \mathrm{B}, \mathrm{Ba}, \mathrm{Al}, \mathrm{Cr}, \mathrm{Cd}, \mathrm{Ni}, \mathrm{Mn}$ and $\mathrm{Se}$ ), ionic concentration $\left(\mathrm{HCO}_{3}, \mathrm{CO}_{3}, \mathrm{Cl}, \mathrm{SO}_{4}\right.$, $\mathrm{Na}, \mathrm{K}, \mathrm{Ca}, \mathrm{Mg}, \mathrm{NO}_{3}, \mathrm{NO}_{2}, \mathrm{NH}_{4}, \mathrm{~F}, \mathrm{PO}_{4}$ and $\mathrm{CN}$ ) and for microbiological enumeration (total viable count, total and fecal coliforms Escherichia coli, Salmonella spp. and Pseudomonas spp.). The data was analyzed with WHO guidelines/ recommendations. The results of physical analysis indicated that all samples are safe except the groundwater of Kasur and Khanewal District. About $66.67 \%$ samples are out of total suspended solids (TSS) limit. Microbiologically, only six groundwater of Punjab districts are found potable according to WHO limits. In the trace metals analysis, highest level of iron was detected in Jhang while the groundwater of three districts were not potable due to high level of boron and nickel but the groundwater of all districts was found safe with respect to $\mathrm{Ba}, \mathrm{Al}$ and $\mathrm{Cr}$. As far as ionic concentration is concerned, 11 districts were found not to be within WHO limit in the case of bicarbonates, seven in phosphates, five in floride, and eight in calcium and potassium. Only 10 districts fall within the limit of chlorine and all samples showed satisfactory results in the case of $\mathrm{CN} \mathrm{CO}_{3}, \mathrm{NO}_{2}$, $\mathrm{NO}_{3}, \mathrm{Mg}, \mathrm{SO}_{4}$ and $\mathrm{NH}_{4}$.
\end{abstract}

Key words: Groundwater, physicochemical, ionic concentration, traces elements, microbiology, WHO guidelines/recommendations.

\section{INTRODUCTION}

The quality of groundwater is the resultant of all the processes and reactions that act on the water from the surroundings and it varies from place to place and with depth of the water table (Reid et al., 2003). Groundwater has many unique characteristics which makes it suitable for public use. It is naturally found in sterile conditions (Mondal et al., 2007). Groundwater particularly accounts for the supply of safe drinking water in rural areas, where

*Corresponding author. E-mail: ahassan.pcsir@gmail.com.

Author(s) agree that this article remain permanently open access under the terms of the Creative Commons Attribution License 4.0 International License 
population is dispersed. For proper infrastructure, a high cost treatment setup and transportation of surface water are needed (Langeneggar, 1990).

Unfortunately, in Pakistan, the availability of groundwater is not unlimited nor is it safe for drinking purpose. The problem of groundwater pollution in several parts of the country has become so acute that extensive groundwater resources may be damaged (Gunkel et al, 2007).

There are many reasons and sources of contamination to the groundwater, for example, land disposal of solid wastes, sewage disposal on land, agricultural activities, urban runoff and polluted surface water (Laluraj et al., 2005). The suitability of groundwater has been examined with reference to WHO (2004) and NEQS (2002) standards.

The quality of groundwater in some parts of the Pakistan is changing as a result of human activities. Bacteria occasionally find their way into groundwater, sometimes in dangerously high concentrations. But freedom from bacteria alone does not mean that the water is fit to drink (Khalafalla, 1993; Babiker and Muhammad, 2014). Many unseen dissolved minerals and organic constituents are present in groundwater in various concentrations. Most are harmless or even beneficial; though occurring infrequently, others are harmful, and few may be highly toxic (Longe and Balogun, 2010). Water typically is not considered fit for drinking if the quality of dissolved minerals exceeds 1000 $\mathrm{mg} / \mathrm{L}$. Water with a few thousand $\mathrm{mg} / \mathrm{L}$ of dissolved minerals is classed as slightly saline, but sometimes used in areas where less-mineralized water is not available (WHO, 2004). These dissolved minerals can be hazardous to animals and plants in large concentration; for example too much sodium in the water may be harmful to the people who have heart problem. Boron is the mineral that is good for plants in small amount but it is toxic to some plants in only slight higher concentration. Water that contains a lot of calcium and magnesium is said to be hard. The very hard water is not desirable for many domestic uses; it will leave a scaly deposit on the inside of pipes, boilers and tanks. Groundwater, especially if acidic, in many places contains excessive amount of iron. Iron causes reddish stain on plumbing fixtures and clothing (Mondal et al., 2007).

In recent years, the growth of industry, technology, population and water use has increased the stress on both our land and water resources. Locally, the quality of groundwater has been degraded (Langeneggar, 1990). Municipal and industrial wastes and chemical fertilizers, herbicides and pesticides not properly curtailed have entered into the soil, infiltered some aquifers, and degraded the groundwater quality. Other pollution problems include sewage leakage, faulty septic-tank operation and landfill leachates (Woods, 1990).

In this study, the portability of groundwater of 36 districts of the Punjab province, Pakistan has been assessed for physical, chemical and microbiological quality.

\section{MATERIALS AND METHODS}

\section{Samples collection}

The samples were collected during March-September, 2012 from different locations of 36 districts of Punjab that are being extensively used for drinking and other domestic purposes (Figure 1). The water samples were taken from average depth of $25-35 \mathrm{~m}$. All water samples were collected in sterile glass Schott bottles $(5 \mathrm{~L})$. While sampling, some parameters like $\mathrm{pH}$ and conductance were measured in the field by using portable kits. For other parameters, samples were stored and transported in a cool box kept below $4^{\circ} \mathrm{C}$ (APHA, 2005). The detailed chemical and microbiological analyses were performed as soon as the samples were carried to the laboratory. All tests were performed in triplicate on the random appropriate sampling from each district.

\section{Microbiological analysis}

All samples were examined using standard methods of APHA (2005).

\section{Physicochemical analysis}

The physico-chemical parameters were determined according to procedures outlined in the Standard Methods for the Examination of Water and Wastewater (APHA, 2005). Turbidity was measured with a HACH $2100 \mathrm{P}$ Turbidimeter. Sodium and potassium were measured by flame emission photometry, trace metals by atomic absorption spectrophotometer, calcium and magnesium by EDTA titration, sulphate by the turbidimetric method, colour by colour comparator and chloride by argentometric tittration. Other analyses included alkalinity by strong acid titration method. Nutrients (nitratenitrogen and phosphate-phosphorous) were determined using Dionex-80 ion analyzer and ammonium by direct nesslerisation and spectrophoto-metric determination at $410 \mathrm{~nm}$. Fluoride was determined by SPADNS method, total dissolved solids and suspended solids were measured gravimetrically after drying in an oven to a constant weight at $105^{\circ} \mathrm{C}$. Table 1 shows the name of districts of the Punjab, from where the samples of water were collected, with their area and population density (people $/ \mathrm{km}^{2}$ ).

\section{RESULTS AND DISCUSSION}

\section{Physical analysis}

As far as physical parameters of the collected samples are concerned, the color and odor of all samples are within the WHO limits (WHO, 2004) except the groundwater of Kasur District. The pH dropped to 5.20 in groundwater of Kasur while the samples collected from Khanewal was found to be alkaline with $\mathrm{pH}$ of 8.83 while the rest samples fall within the recommended range (6.58.5). According to WHO guidelines, the total suspended solids (TSS) should be zero; but about $66.67 \%$ samples are out of range. In this study, the conductivity of the collected samples is observed above permissible limits of WHO. The results of physical parameters of selected 


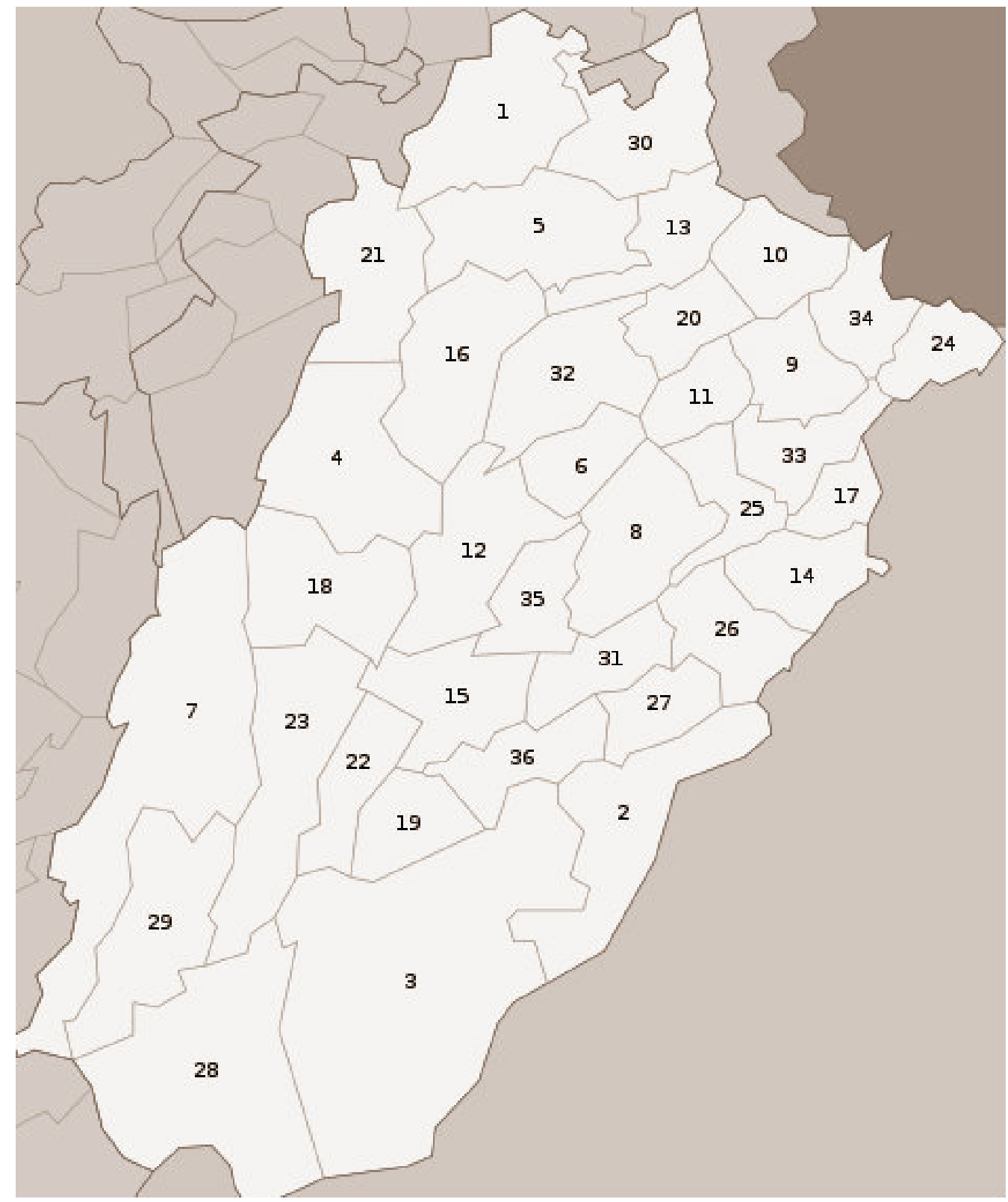

Figure 1. Map of districts of Punjab (refer to Table 1).

samples, along with WHO recommended limits are shown in Table 2.

\section{Microbiological analysis}

The most basic test for bacterial contamination of a water supply is the test for total coliform bacteria (Styenberg et al., 1995). Total coliform counts give a general indication of the sanitary condition of a water supply. Total coliforms include bacteria that are found in the soil and in water that has been influenced by surface water, and in human or animal waste (Atherholt et al., 2003). Fecal coliforms are the group of the total coliforms that are considered to be present specifically in the gut and feces of warmblooded animals (Crysup and Mott, 2001). If fecal coliform counts are high (over 200 colonies per $100 \mathrm{ml}$ of water sample), there is a greater chance that pathogenic organisms are also present. Diseases and illnesses such as typhoid fever, hepatitis, gastroenteritis, dysentery and ear infections can be contracted in waters with high fecal coliform counts (Francy et al., 2000). According to WHO recommendations/ guidelines, drinking water must have zero total coliforms, fecal coliforms and E. coli (WHO, 2004). The results of the present study show that only $22 \%$ groundwater samples are found according to the 
Table 1. Information on the selected districts of Punjab.

\begin{tabular}{|c|c|c|c|}
\hline District name & Area $\left(\mathrm{km}^{2}\right)$ & Population (1998) & Density (people/km²) \\
\hline Attock & 6,858 & $1,274,935$ & 186 \\
\hline Bahawalnagar & 8,878 & $2,061,447$ & 232 \\
\hline Bahawalpur & 24,830 & $2,433,091$ & 98 \\
\hline Bhakkar & 8,153 & $1,051,456$ & 129 \\
\hline Chakwal & 6,524 & $1,083,725$ & 166 \\
\hline Chiniot & & 965,124 & \\
\hline Dera Ghazi Khan & 11,922 & $1,643,118$ & 138 \\
\hline Faisalabad & 5,856 & $5,429,547$ & 927 \\
\hline Gujranwala & 3,622 & $3,400,940$ & 939 \\
\hline Gujrat & 3,192 & $2,048,008$ & 642 \\
\hline Hafizabad & 2,367 & 832,980 & 352 \\
\hline Jhang & 8,809 & $2,834,545$ & 322 \\
\hline Jhelum & 3,587 & 936,957 & 261 \\
\hline Kasur & 3,995 & $2,375,875$ & 595 \\
\hline Khanewal & 4,349 & $2,068,490$ & 476 \\
\hline Khushab & 6,511 & 905,711 & 139 \\
\hline Lahore & 1,772 & $6,318,745$ & 3,566 \\
\hline Layyah & 6,291 & $1,120,951$ & 178 \\
\hline Lodhran & 2,778 & $1,171,800$ & 422 \\
\hline Mandi Bahauddin & 2,673 & $1,160,552$ & 434 \\
\hline Mianwali & 5,840 & $1,056,620$ & 181 \\
\hline Multan & 3,720 & $3,116,851$ & 838 \\
\hline Muzaffargarh & 8,249 & $2,635,903$ & 320 \\
\hline Narowal & 2,337 & $1,265,097$ & 541 \\
\hline Nankana Sahib & 2,960 & $1,410,000$ & \\
\hline Okara & 4,377 & $2,232,992$ & 510 \\
\hline Pakpattan & 2,724 & $1,286,680$ & 472 \\
\hline Rahim Yar Khan & 11,880 & $3,141,053$ & 264 \\
\hline Rajanpur & 12,319 & $1,103,618$ & 90 \\
\hline Rawalpindi & 5,286 & $3,363,911$ & 636 \\
\hline Sahiwal & 3,201 & $1,843,194$ & 576 \\
\hline Sargodha & 5,854 & $2,665,979$ & 455 \\
\hline Sheikhupura & 5,960 & $3,321,029$ & 557 \\
\hline Sialkot & 3,016 & $2,723,481$ & 903 \\
\hline Toba Tek Singh & 3,252 & $1,621,593$ & 499 \\
\hline Vehari & 4,364 & $2,090,416$ & 479 \\
\hline
\end{tabular}

limit of WHO for total coliforms, only eight districts are found free of $E$. coli. The 13 districts are found contaminated with Salmonella spp. while only eight districts groundwater was free from the Pseudomonas spp. Overall, only six groundwater of Punjab districts are found potable according to WHO limits. The results of microbiological analysis are shown in Table 3.

\section{Trace metals analysis}

The results of trace metals are shown in Table 4, according to this study, the highest level of iron (Fe) was detected in Jhang (0.89) and overall groundwater of 17 districts were found to be outside the range of recommended limits of WHO. Infact, iron is one of the most worrying elements in water supplies (Pradhan et al., 2001). Rainwater as it infiltrates the soil and underlying geologic formations dissolves iron, causing it to seep into aquifers that serve as sources of groundwater for wells (Marian, 1991). Iron and manganese (Mn) are common water contaminants that are not considered health hazards. Their presence in water results in staining as well as offensive tastes and appearances. As groundwater flows through sediments, metals such as iron and manganese $(\mathrm{Mn})$ are dissolved and may later be found 
Table 2. Physical parameters for 36 districts of Punjab.

\begin{tabular}{|c|c|c|c|c|c|}
\hline Location & Color & Odor & $\mathrm{pH}$ at $26^{\circ} \mathrm{C}$ & Conductivity $(\mu \mathrm{s} / \mathrm{cm})$ & TSS (mg/L) \\
\hline Attock & Colorless & Odorless & 8.23 & 679 & N.D \\
\hline Bahawalnagar & Colorless & Odorless & 8.29 & 685 & N.D \\
\hline Bahawalpur & Colorless & Odorless & 8.03 & 46300 & 36.0 \\
\hline Bhakkar & Colorless & Odorless & 7.81 & 887 & N.D \\
\hline Chakwal & Colorless & Odorless & 8.19 & 276 & N.D \\
\hline Chiniot & Colorless & Odorless & 8.44 & 12960 & 52.0 \\
\hline Dera Ghazi Khan & Colorless & Odorless & 7.20 & 140 & N.D \\
\hline Faisalabad & Colorless & Odorless & 8.23 & 889 & N.D \\
\hline Gujranwala & Colorless & Odorless & 8.29 & 112 & N.D \\
\hline Gujrat & Colorless & Odorless & 8.03 & 5566 & 61.0 \\
\hline Hafizabad & Colorless & Odorless & 7.81 & 678 & N.D \\
\hline Jhang & Colorless & Odorless & 8.19 & 431 & N.D \\
\hline Jhelum & Colorless & Odorless & 8.44 & 569 & N.D \\
\hline Kasur & Colored & Odorless & 5.20 & 9888 & 43.9 \\
\hline Khanewal & Colorless & Odorless & 8.83 & 8886 & N.D \\
\hline Khushab & Colorless & Odorless & 8.09 & 909 & N.D \\
\hline Lahore & Colorless & Odorless & 8.04 & 213 & 23.6 \\
\hline Layyah & Colorless & Odorless & 7.25 & 2006 & 19.9 \\
\hline Lodhran & Colorless & Odorless & 8.11 & 334 & N.D \\
\hline Mandi Bahauddin & Colorless & Odorless & 8.49 & 554 & 55.1 \\
\hline Mianwali & Colorless & Odorless & 7.29 & 665 & N.D \\
\hline Multan & Colorless & Odorless & 7.20 & 881 & N.D \\
\hline Muzaffargarh & Colorless & Odorless & 8.03 & 332 & N.D \\
\hline Narowal & Colorless & Odorless & 8.01 & 321 & 39.0 \\
\hline Nankana Sahib & Colorless & Odorless & 7.24 & 456 & N.D \\
\hline Okara & Colorless & Odorless & 8.29 & 667 & N.D \\
\hline Pakpattan & Colorless & Odorless & 7.44 & 119 & N.D \\
\hline Rahim Yar Khan & Colorless & Odorless & 7.20 & 443 & N.D \\
\hline Rajanpur & Colorless & Odorless & 7.23 & 663 & N.D \\
\hline Rawalpindi & Colorless & Odorless & 8.21 & 459 & 22.9 \\
\hline Sahiwal & Colorless & Odorless & 8.00 & 442 & 16.0 \\
\hline Sargodha & Colorless & Odorless & 7.89 & 112 & N.D \\
\hline Sheikhupura & Colorless & Odorless & 8.09 & 11001 & N.D \\
\hline Sialkot & Colorless & Odorless & 7.44 & 445 & 22.0 \\
\hline Toba Tek Singh & Colorless & Odorless & 7.01 & 111 & N.D \\
\hline Vehari & Colorless & Odorless & 6.99 & 236 & 45.9 \\
\hline WHO & Colorless & Odorless & $6.5-8.5$ & 14.00 & N.D \\
\hline
\end{tabular}

in high concentrations in water. Industrial discharges, urban activities, agriculture, groundwater pumages and disposal of waste can all affect groundwater quality (Kjoller et al., 2004).

Copper is a metal that occurs naturally in rock, soil, plants, animals and water (Kerbyson and Schandorf, 1966). The level of copper in surface and groundwater is generally very low. High levels of copper may get into the environment through mining, farming, manufacturing operations and municipal or industrial wastewater releases into rivers and lakes. Copper can get into drinking water either directly by contaminating well water or through corrosion of copper pipes if water is acidic. Corrosion of pipes is by far the greatest cause for concern. In human, its causes stomach and intestinal diseases, liver and kidney damage in high doses. But in this study, fortunately all samples were found within limits of WHO for copper concentration.

Boron is the mineral that is good for plants in small amount but it is toxic to some plants in only slight higher concentration and nickel may be found in slate, sandstone, clay minerals and basalt. The main nickel source is pentlandite (Atherholt et al., 2003). Nickel is a dietary requirement for a number of organisms, therefore 
Table 3. Microbiological analysis of groundwater samples.

\begin{tabular}{|c|c|c|c|c|c|c|}
\hline Location & $\begin{array}{c}\text { Viable } \\
\text { count } / \mathrm{ml}\end{array}$ & $\begin{array}{c}\text { Total coliforms } \\
\text { (MPN/100 ml) }\end{array}$ & $\begin{array}{c}\text { Fecal coliforms } \\
\text { (MPN/100 ml) }\end{array}$ & $\begin{array}{c}\text { E. coli } \\
\text { (MPN/100 ml) }\end{array}$ & $\begin{array}{l}\text { Salmonella } \\
\text { spp. } 125 \mathrm{ml}\end{array}$ & $\begin{array}{c}\text { Pseudomonas } \\
\text { spp. (MPN/100ml) }\end{array}$ \\
\hline Attock & $90 * 10^{3}$ & 94 & 70 & 33 & Detected & 17 \\
\hline Bahawalnagar & $8.5^{\star} 10^{2}$ & 24 & 20 & 23 & N.D & 23 \\
\hline Bahawalpur & $1.9 * 10^{4}$ & 94 & 49 & 80 & Detected & 23 \\
\hline Bhakkar & $1.2 * 10^{2}$ & N.D & N.D & N.D & N.D & N.D \\
\hline Chakwal & $5.0 * 10^{2}$ & N.D & N.D & N.D & N.D & N.D \\
\hline Chiniot & $6.2 * 10^{2}$ & 70 & 39 & 31 & N.D & 17 \\
\hline Dera Ghazi Khan & $23^{\star} 10^{3}$ & 84 & 70 & 33 & N.D & 11 \\
\hline Faisalabad & $4.5 * 10^{2}$ & 24 & 20 & 23 & N.D & 23 \\
\hline Gujranwala & $9.9 * 10^{4}$ & 40 & 20 & 20 & Detected & 4.0 \\
\hline Gujrat & $1.4 * 10^{2}$ & 14 & 14 & N.D & N.D & 2.0 \\
\hline Hafizabad & $5.5^{\star} 10^{3}$ & N.D & N.D & N.D & N.D & N.D \\
\hline Jhang & $6.7 * 10^{2}$ & 40 & 17 & 31 & Detected & 6.8 \\
\hline Jhelum & $60 \star 10^{3}$ & 70 & 63 & 33 & Detected & 11 \\
\hline Kasur & $8.7 * 10^{1}$ & 33 & 20 & 23 & N.D & 23 \\
\hline Khanewal & $3.9 * 10^{4}$ & 94 & 49 & 80 & Detected & 20 \\
\hline Khushab & $1.5 * 10^{2}$ & N.D & N.D & N.D & N.D & N.D \\
\hline Lahore & $5.9 * 10^{2}$ & 14 & 11 & 4.5 & N.D & 4.5 \\
\hline Layyah & $1.2 * 10^{2}$ & 21 & 11 & 11 & Detected & 17 \\
\hline Lodhran & $50 \star 10^{2}$ & 94 & 70 & 33 & N.D & 14 \\
\hline Mandi Bahauddin & $8.5 * 10^{2}$ & 24 & 20 & 23 & N.D & 23 \\
\hline Mianwali & $1.0 * 10^{4}$ & 94 & 49 & 80 & Detected & 33 \\
\hline Multan & $1.5 * 10^{2}$ & 11 & 6.8 & 2.0 & N.D & N.D \\
\hline Muzaffargarh & $5.4 * 10^{5}$ & N.D & N.D & N.D & N.D & N.D \\
\hline Narowal & $6.5 * 10^{2}$ & 48 & 39 & 31 & Detected & 17 \\
\hline Nankana Sahib & $76 * 10^{3}$ & 70 & 47 & 33 & Detected & 6.8 \\
\hline Okara & $8.4 * 10^{2}$ & 24 & 20 & 23 & N.D & 23 \\
\hline Pakpattan & $1.1 * 10^{4}$ & 84 & 49 & 80 & N.D & 33 \\
\hline Rahim Yar Khan & $1.3^{*} 10^{4}$ & 120 & 110 & 39 & Detected & N.D \\
\hline Rajanpur & $5.2 * 10^{2}$ & 33 & 33 & N.D & N.D & 2.0 \\
\hline Rawalpindi & $2.2 * 10^{2}$ & 26 & 11 & 17 & N.D & 17 \\
\hline Sahiwal & $40 * 10^{3}$ & 70 & 63 & 33 & N.D & 20 \\
\hline Sargodha & $1.5^{\star} 10^{1}$ & 17 & 20 & 23 & N.D & 23 \\
\hline Sheikhupura & $6.9 * 10^{4}$ & 63 & 49 & 33 & Detected & 7.8 \\
\hline Sialkot & $2.2 * 10^{2}$ & N.D & N.D & N.D & N.D & 2.0 \\
\hline Toba Tek Singh & $3.9 * 10^{2}$ & N.D & N.D & N.D & N.D & N.D \\
\hline Vehari & $3.1 * 10^{4}$ & 40 & 11 & 24 & Detected & 14 \\
\hline WHO & - & Zero & Zero & Zero & N.D & Zero \\
\hline
\end{tabular}

*N.D $=$ Not detected.

it might be of significance to humans (MacCutcheon et al., 1983). Nickel compounds may be toxic in high concentrations, but these are often water insoluble, limiting potential harm (Singh and Lawrence, 2007). Results show that the groundwater of three districts could not be potable due to high level of boron (B) and $\mathrm{Ni}$ in groundwater.

Four districts are found not to be within WHO limits for cadmium which is found in rocks, coals and petroleum and enters the ground and surface water when dissolved by acidic waters. It causes kidney damage, anemia, high blood pressure and liver damage.

Selenium (Se) occurs naturally in the environment. Selenium that is immobile and will not dissolve in water is less of a risk to organisms. The oxygen levels in the soil and the acidity of the soil will increase mobile forms of selenium. Higher oxygen levels and increased acidity of soils is usually cause by human activities such as industrial and agricultural processes (Kerbyson and Schandorf, 1966). Humans may be exposed to selenium 
Table 4. Trace metals (mg/L) analysis of groundwater samples.

\begin{tabular}{|c|c|c|c|c|c|c|c|c|c|c|}
\hline Location & $\mathrm{Fe}$ & $\mathrm{Cu}$ & B & $\mathrm{Ba}$ & Al & $\mathrm{Cr}$ & Cd & $\mathrm{Ni}$ & Mn & $\mathrm{Se}$ \\
\hline Attock & 0.78 & N.D & 0.214 & N.D & N.D & N.D & 0.01 & 0.29 & 0.09 & N.D \\
\hline Bahawalnagar & 0.11 & N.D & .4 & 0.2 & N.D & N.D & J.D & V.D & 0.02 & N.D \\
\hline Bahawalpur & 0.34 & N.D & 0.47 & 0.1 & N.D & N.D & N.D & N.D & N.D & N.D \\
\hline Bhakkar & 0.36 & N.D & 1.91 & 0.1 & N.D & N.D & N.D & N.D & N.D & N.D \\
\hline Chakwal & 0.21 & 0.055 & N.D & N.D & N.D & N.D & N.D & 0.01 & N.D & N.D \\
\hline Chiniot & 0.33 & N.D & N.D & N.D & N.D & N.D & N.D & N.D & N.D & N.D \\
\hline Dera Ghazi Khan & 0.71 & N.D & 0.20 & N.D & N.D & N.D & N.D & 0.25 & N.D & N.D \\
\hline Faisalabad & 0.35 & N.D & 0.46 & 0.2 & N.D & N.D & N.D & N.D & N.D & N.D \\
\hline Gujranv & 0.34 & N.D & N.D & 0.1 & N.D & N.D & N.D & N.D & N.D & N.D \\
\hline Gujrat & 0.22 & N.D & N.D & 0.1 & N.D & N.D & N.D & N.D & N.D & N.D \\
\hline Hafizab & 0.21 & 0.051 & N.D & N.D & N.D & N.D & N.D & N.D & N.D & N.D \\
\hline Jhang & 0.89 & N.D & N.D & N.D & N.D & N.D & 0.03 & N.D & 0.01 & N.D \\
\hline Jhelum & 0.71 & N.D & 0.46 & N.D & N.D & N.D & N.D & N.D & 0.10 & N.D \\
\hline Kasur & 0.15 & N.D & 0.55 & 0.2 & N.D & N.D & N.D & N.D & N.D & N.D \\
\hline Khanew & 0.25 & N.D & 0.42 & 0.1 & N.D & N.D & N.D & 0.14 & N.D & N.D \\
\hline Khusl & 0.16 & N.D & 0.33 & 0.1 & N.D & N.D & N.D & N.D & N.D & N.D \\
\hline Lahore & 0.26 & 0.021 & 0.41 & N.D & N.D & N.D & N.D & N.D & N.D & N.D \\
\hline Layyah & 0.30 & N.D & N.D & N.D & N.D & N.D & N.D & N.D & 0.03 & N.D \\
\hline Lodhran & 0.77 & N.D & 0.14 & N.D & N.D & N.D & 0.02 & N.D & N.D & N.D \\
\hline Mandi $\mathrm{Ba}$ & 0.19 & N.D & N.D & 0.2 & N.D & N.D & N.D & N.D & N.D & N.D \\
\hline Mianwali & 0.36 & N.D & N.D & 0.1 & N.D & N.D & N.D & N.D & N.D & N.D \\
\hline Multan & 0.16 & 0.022 & 1.99 & 0.1 & N.D & N.D & N.D & N.D & N.D & N.D \\
\hline Muzaffargarh & 0.26 & 0.020 & 0.4 & N.D & N.D & N.D & N.D & 0.01 & N.D & N.D \\
\hline Narowal & 0.34 & N.D & N.D & N.D & N.D & N.D & N.D & N.D & N.D & N.D \\
\hline Nankana & 0.28 & N.D & 0.11 & N.D & N.D & N.D & N.D & 0.21 & N.D & N.D \\
\hline Okara & 0.10 & N.D & 0.41 & 0.2 & N.D & N.D & N.D & N.D & 0.02 & N.D \\
\hline Pakpattan & 0.35 & N.D & 0.42 & 0.1 & N.D & N.D & N.D & N.D & N.D & N.D \\
\hline Rahim Yar & 0.46 & N.D & 1.12 & 0.1 & N.D & N.D & N.D & N.D & N.D & N.D \\
\hline Rajanpur & 0.25 & N.D & N.D & N.D & N.D & N.D & N.D & N.D & N.D & N.D \\
\hline Rawalpind & 0.32 & N.D & N.D & N.D & N.D & N.D & N.D & N.D & N.D & N.D \\
\hline Sahiwal & 0.74 & N.D & 0.81 & N.D & N.D & N.D & 0.01 & 0.03 & N.D & N.D \\
\hline Sargodha & 0.11 & N.D & 0.41 & 0.2 & N.D & N.D & N.D & N.D & N.D & N.D \\
\hline Sheikhupura & 0.45 & N.D & 0.70 & 0.1 & N.D & N.D & N.D & N.D & N.D & N.D \\
\hline Sialkot & 0.26 & N.D & 1.60 & 0.1 & N.D & N.D & N.D & N.D & N.D & N.D \\
\hline Toba Tek Singh & 0.21 & 0.028 & 0.10 & N.D & N.D & N.D & N.D & 0.02 & N.D & N.D \\
\hline Vehari & 0.31 & N.D & N.D & N.D & N.D & N.D & N.D & N.D & 0.02 & N.D \\
\hline WHO & 0.30 & 1.0 & 1.0 & 1.0 & 0.02 & 0.10 & 0.00 & 0.05 & 0.10 & N.D \\
\hline
\end{tabular}

in several ways. Fortunately, all districts groundwater were found safe in the sense of Se.

Barium can cause a variety of cardiac, gastrointestinal and neuromuscular effects. Aluminum occurs naturally in some rocks and drainage from mines. It can precipitate out of water after treatment, causing increased turbidity or dissolved water (Marian, 1991). Chromium has the potential to damage liver, kidney, circulatory and nerve tissues; and cause skin irritation. When released into land, chromium compounds bind to soil and are not likely to migrate to groundwater. They are very persistent in water as sediments. There is a high potential for accumulation of chromium in aquatic life (Singh and Lawrence, 2007) and the results has shown that groundwater of all districts was found safe with respect to $\mathrm{Ba}, \mathrm{Al}$, and $\mathrm{Cr}$. 


\section{Ions concentration analysis}

The presence of carbonates, bicarbonates and hydroxides are the main causes of the alkalinity in the natural water. Bicarbonates represent the major form since they are formed in considerable amount in the soil (MacCutcheon et al., 1983). In this study, we found that 11 districts were outside the WHO limit.

While phosphates limit was exceeded in seven districts, fluoride in five districts, and calcium in eight districts. The fluoride concentration is present in soil strata and the accumulation of fluoride in soil strata results in the leaching process due to percolating water pressure resulting to increased fluoride concentration in groundwater (O'Neil, 1993). When the concentration of phosphates rises, the coagulation processes in drinking water treatment plants may be adversely affected. Manmade sources of phosphate include human sewage, agricultural run-off from crops, sewage from animal feedlots, pulp and paper industry, vegetable and fruit processing, chemical and fertilizer manufacturing and detergents (Marian, 1991).

Only 10 districts samples were found in the limit in the case of chlorine $(\mathrm{Cl})$ and all samples showed satisfactory results in the case of $\mathrm{CN}, \mathrm{CO}_{3}, \mathrm{NO}_{2}, \mathrm{NO}_{3}, \mathrm{Mg}, \mathrm{SO}_{4}$ and $\mathrm{NH}_{4}$. Nitrate is effective plant nutrient and moderately toxic and is considered important for its adverse health effects (Jain and Ram, 1996). The higher nitrate concentration may be attributed to combined effect of contamination from domestic sewage and runoff from fertilized fields (Langanegger, 1987) and cyanides are generally not persistent when released into water or soil, and are not likely to accumulate in aquatic life. They rapidly evaporate and are broken down by microbes. They do not bind to soils and may leach to groundwater. EPA has found cyanide to potentially cause the following health effects when people are exposed to it at levels above the MCL for relatively short periods of time: rapid breathing, tremors and other neurological effects (Marian, 1991).

In the present study, all samples showed satisfactory results for ammonia. $\mathrm{NH}_{3}$ is the principal form of toxic ammonia. It has been reported toxic to fresh water organisms at concentrations ranging from 0.53 to 22.8 $\mathrm{mg} / \mathrm{L}$ (DWAF, 1998). Toxic concentrations of ammonia in humans may cause loss of equilibrium, convulsions, coma and death (Bolalak and Frankowaski, 2003). The sulphate contents of water may change significantly with time during infiltration of rainfall and groundwater recharge, which mostly takes place from stagnant pools, puddles and surface runoff water collected in low-lying areas. All samples showed satisfactory results in this study. All samples showed satisfactory results for sodium in this study except that from Gujrat. In fact, sodium concentration more than $50 \mathrm{mg} / \mathrm{L}$ make the water unsuitable for domestic use.

Eight districts were found to have unfit groundwater in the case of potassium, with highest value in Mianwali (120 mg/L), which naturally occurs in various minerals, from which it may be dissolved through weathering processes (Chapman, 1996). Potassium plays a central role in plant growth, and it often limits it. Potassium from dead plant and animal material is often bound to clay minerals in soils, before it dissolves in water (O'Neil 1993).

\section{Conclusion}

This study has provided information on the water quality status of groundwater from 36 districts of the Punjab, Pakistan. The physical, chemical and microbiological qualities were assessed. The results of physical analysis indicated that $\mathrm{pH}$, color and odor were all within their natural background levels of 6.5-8.5 except the groundwater of Kasur and Khanewal District. According to WHO guidelines, the total suspended solids (TSS) should be zero but about $66.67 \%$ samples are not within this limit. In this study, the conductivity of all the collected samples is observed above permissible limits of WHO.

According to $\mathrm{WHO}$ recommendations/guidelines, drinking water must have zero total coliforms, fecal coliforms and $E$. coli (WHO, 2004). Results of the present study show that only $22 \%$ groundwater samples are found according to the limit of WHO for total coliforms, only eight districts are found free of $E$. coli. 13 districts are found to samples contaminated with Salmonella spp., while only eight districts groundwater were free from the Pseudomonas spp. Overall, only six groundwater samples of Punjab districts are found potable according to WHO limits.

In the trace metals analysis, highest level of iron (Fe) was detected in Jhang (0.89) and overall groundwater of 17 districts were found to be out of the recommended limits of WHO while the groundwater of three districts could not be potable due to high level of boron and $\mathrm{Ni}$ in groundwater. The results of the present study has shown that groundwater of all districts was found safe with respect to $\mathrm{Ba}, \mathrm{Al}$ and $\mathrm{Cr}$.

As far as ionic concentration is concerned, the 11 districts were found not to be within the WHO limit in the case of bicarbonates while phosphates limit was exceeded in seven districts, fluoride limit was exceeded in five districts, and calcium limit was exceeded in eight districts Table 5. Only ten districts samples were found within the limit in the case of chlorine $(\mathrm{Cl})$ and all samples showed satisfactory results in the case of $\mathrm{CN}, \mathrm{CO}_{3}, \mathrm{NO}_{2}$, $\mathrm{NO}_{3}, \mathrm{Mg}, \mathrm{SO}_{4}$ and $\mathrm{NH}_{4}$ and eight districts are found to have unfit groundwater in the case of potassium, with highest value in Mianwali (120 mg/L).

\section{Conflict of interest}

The authors declare that they have no conflict of interest. 
Table 5. Ionic concentration ( $\mathrm{mg} / \mathrm{L}$ ) analysis of groundwater samples

\begin{tabular}{|c|c|c|c|c|c|c|c|c|c|c|c|c|c|c|}
\hline Location & $\mathrm{HCO}_{3}$ & $\mathrm{CO}_{3}$ & $\mathrm{Cl}$ & $\mathrm{SO}_{4}$ & $\mathrm{Na}$ & $\mathrm{K}$ & $\mathrm{Ca}$ & $\mathrm{Mg}$ & $\mathrm{NO}_{3}$ & $\mathrm{NO}_{2}$ & $\mathrm{NH}_{4}$ & $F$ & $\mathrm{PO}_{4}$ & $\mathrm{CN}$ \\
\hline Attock & 261.8 & N.D & 35.0 & 51.6 & 116 & 1.57 & 8.0 & 3.4 & N.D & N.D & N.D & 0.15 & N.D & N.D \\
\hline Bahawalnagar & 225.0 & N.D & 27.2 & 29.0 & 95 & 5.09 & 14.06 & 8.54 & 50.0 & N.D & N.D & N.D & N.D & N.D \\
\hline Bahawalpur & 233.6 & N.D & 121.0 & 69.9 & 248 & 110 & 820 & 11.5 & N.D & N.D & N.D & N.D & N.D & N.D \\
\hline Bhakkar & 356.0 & N.D & 80.97 & 79.0 & 86 & 6.0 & 40 & 15.5 & N.D & N.D & 0.85 & 0.25 & 0.25 & N.D \\
\hline Chakwal & 121.3 & N.D & 19.9 & 11.0 & 10.2 & 2.1 & 16 & 14.58 & N.D & N.D & N.D & 1.5 & N.D & N.D \\
\hline Chiniot & 583.7 & N.D & 2603 & 78.0 & 180 & 40.8 & 102 & 191.0 & N.D & N.D & 1.02 & N.D & N.D & N.D \\
\hline Dera Ghazi Khan & 241.8 & N.D & 35.9 & 12.6 & 121 & 1.52 & 8.0 & 3.1 & N.D & N.D & N.D & 0.12 & N.D & N.D \\
\hline Faisalabad & 229.0 & N.D & 270.2 & 29.0 & 9.51 & 59.1 & 14.06 & 8.4 & 5.0 & N.D & N.D & N.D & N.D & N.D \\
\hline Gujranwala & 222.6 & N.D & 221.0 & 67.0 & 222 & 90 & 820 & 16.5 & N.D & N.D & N.D & N.D & 1.02 & N.D \\
\hline Gujrat & 339.0 & N.D & 180.9 & 41.0 & 281 & 63.0 & 40 & 25.5 & N.D & N.D & N.D & N.D & N.D & N.D \\
\hline Hafizabad & 126.0 & N.D & 19.2 & 48.0 & 100 & 32.0 & 16 & 12.21 & N.D & N.D & N.D & 2.52 & N.D & N.D \\
\hline Jhang & 512.5 & N.D & 280.1 & 23.0 & 181 & 10.0 & 102 & 17.9 & N.D & N.D & N.D & N.D & N.D & N.D \\
\hline Jhelum & 221.8 & N.D & 35.1 & 24.6 & 102 & 1.23 & 8.0 & 3.1 & N.D & N.D & N.D & 0.15 & N.D & N.D \\
\hline Kasur & 223.0 & N.D & 22.9 & 15.0 & 91 & 5.01 & 14.06 & 8.4 & N.D & N.D & N.D & N.D & N.D & N.D \\
\hline Khanewal & 133.6 & N.D & 121.1 & 61.0 & 24.8 & 112 & 820 & 11.5 & N.D & N.D & N.D & N.D & N.D & N.D \\
\hline Khushab & 219.0 & N.D & 820.9 & 41.0 & 85.1 & 60.0 & 40 & 15.5 & N.D & N.D & 0.81 & N.D & N.D & N.D \\
\hline Lahore & 131.3 & N.D & 192.9 & 22.0 & 10.21 & 2.12 & 16 & 11.58 & N.D & N.D & 1.00 & 2.5 & 0.50 & N.D \\
\hline Layyah & 623.7 & N.D & 260.1 & 23.0 & 124 & 40.3 & 102 & 13.0 & N.D & N.D & 1.06 & 4.1 & N.D & N.D \\
\hline Lodhran & 281.8 & N.D & 35.01 & 65.6 & 11.3 & 1.51 & 8.0 & 3.6 & N.D & N.D & N.D & 0.11 & N.D & N.D \\
\hline Mandi Bahauddin & 229.0 & N.D & 27.98 & 11.0 & 9.25 & 59.0 & 14.06 & 2.4 & 5.12 & N.D & N.D & N.D & N.D & N.D \\
\hline Mianwali & 231.6 & N.D & 129.1 & 61.0 & 243 & 120 & 820 & 10.5 & N.D & N.D & N.D & N.D & N.D & N.D \\
\hline Multan & 322.0 & N.D & 10.97 & 89.0 & 250 & 6.0 & 40 & 11.5 & N.D & N.D & N.D & N.D & N.D & N.D \\
\hline Muzaffargarh & 145.3 & N.D & 101.9 & 21.0 & 123 & 2.0 & 16 & 9.50 & N.D & N.D & N.D & N.D & 0.51 & N.D \\
\hline Narowal & 589.7 & N.D & 269.1 & 75.0 & 142 & 20.9 & 102 & 11.0 & N.D & N.D & 1.02 & N.D & N.D & N.D \\
\hline Nankana Sahib & 261.1 & N.D & 35.1 & 90.6 & 216 & 1.87 & 8.0 & 3.49 & N.D & N.D & N.D & 0.15 & N.D & N.D \\
\hline Okara & 221.3 & N.D & 37.9 & 22.0 & 25 & 5.21 & 14.06 & 8.11 & 5.0 & N.D & N.D & 0.28 & N.D & N.D \\
\hline Pakpattan & 232.8 & N.D & 421.0 & 140.0 & 142 & 119 & 820 & 22.5 & 1.18 & N.D & N.D & N.D & N.D & N.D \\
\hline Rahim Yar Khan & 319.0 & N.D & 280.1 & 35.0 & 231 & 6.96 & 40 & 19.5 & N.D & N.D & N.D & N.D & N.D & N.D \\
\hline Rajanpur & 123.1 & N.D & 49.2 & 24.0 & 129 & 2.33 & 16 & 13.5 & N.D & N.D & N.D & 2.5 & N.D & N.D \\
\hline Rawalpindi & 581.7 & N.D & 260.3 & 92.0 & 180 & 40.3 & 102 & 11.0 & N.D & N.D & N.D & N.D & N.D & N.D \\
\hline Sahiwal & 261.2 & N.D & 350.1 & 21.6 & 189 & 1.51 & 8.0 & 3.47 & N.D & N.D & N.D & 0.19 & N.D & N.D \\
\hline Sargodha & 222.1 & N.D & 76.2 & 20.0 & 90.4 & 52.0 & 14.06 & 8.14 & 50.0 & N.D & N.D & N.D & N.D & N.D \\
\hline Sheikhupura & 233.3 & N.D & 12.11 & 61.0 & 243 & 11.0 & 820 & 6.5 & 4.18 & N.D & N.D & N.D & 1.55 & N.D \\
\hline Sialkot & 329.1 & N.D & 89.8 & 49.0 & 120 & 26.0 & 40 & 15.5 & N.D & N.D & N.D & 1.25 & 0.25 & N.D \\
\hline T.K Singh & 122.3 & N.D & 11.6 & 24.0 & 67.9 & 20.0 & 16 & 14.8 & N.D & N.D & N.D & 2.1 & 0.50 & N.D \\
\hline Vehari & 583.9 & N.D & 26.01 & 96.0 & 231 & 40.0 & 102 & 1.91 & N.D & N.D & 1.01 & 5.0 & N.D & N.D \\
\hline WHO & 300 & N.D & $\begin{array}{c}200- \\
600\end{array}$ & 250 & 250 & 50 & 250 & 50 & 50 & 50 & 50 & 1.5 & N.D & N.D \\
\hline
\end{tabular}

\section{REFERENCES}

American Public Health Association (APHA, 2005). Standard Methods for the Examination of Water and Wastewater. 19th ed. American Water Works Association, Water Environment Federation, Washington.

Atherholt T, Feerst E, Hovendon K, Jae R, Joseph D ( 2003). Evaluation of indicators of fecal contamination in groundwater. Am. Water Works Assoc. 95(10):119-131.

Babiker IS, Mohamed AAM (2014). Groundwater quality assessment using GIS, the case of Omdurman area, central Sudan. 6(1):22-33

Bolalak J, Frankowaski L (2003). Selected nutrients and iron in interstitial, water of the estuary of Southern Baltic in relation to redox potential water and air and soil pollution. J. Am. Sci. 147:39-50.
Chapman D (1996). Water Quality Assessment, 2nd edn. EPFN Spon, London.

Crysup KA, Mott JB (2001). Fecal coliform, enterococci and E.coli as indicators of water quality in the Creek Bay watershed, Corpus Christi, Texas. General Meeting of the American Society for Microbiology, 20-24 May, Orlando, American Society for microbiology, Florida.

DWAF (1998). Quality of Domestic Water Supplies. Assessment Guide, 2nd edn. Department Geol. Survey Bull. 42. Accra, Ghana.

Francy DS, Heise DR, Nally RA (2000). Occurrence and Distribution of microbiological indicators in groundwater and stream water. Water Environment Research 72(2):152-161.

Gunkel G, Kosmol J, Sobral M, Rohn H, Montenegro S, Aureliano J (2007). Sugar cane industry as a source of water pollution-case study 
on the situation in ipojuca river, pernambuco, Brazil. Water, Air, Soil Pollution 180(1-4):261-269.

Kerbyson JD, Schandorf JRH (1966). Chemical analysis of Ghana rocks, Ores and Minerals, pp. 1945-1965.

Khalafalla GM, El-Gizawy SA, Ensaf ID (1993). Bacteriological quality of various drinking water sources. Egypt, J. Appl. Sci. 8:809-822.

Kjøller C, Postma D, Larsen F, Kjøller C, Postma D, Larsen F (2004). Groundwater acidification and the mobilization of trace metals in a sandy aquifer. Environ. Sci. Technol. 38 (10), pp. 2829-2835.

Laluraj CM, Gopinath G, Dineshkumar PK (2005). Groundwater Chemistry of Shallow Aquifers in the Coastal Zones of Cochin, India Appl. Ecol. Environ. Res. 3(1): 133-139.

Langanegger O (1987). Groundwater Quality, An important factor for selecting hand-pumps. BP 1850. 01.

Langeneggar O (1990). Groundwater Quality in Rural Areas of Western Africa. UNDP

Project INT 81(26): 10

Longe EO, Balogun MR (2010). Groundwater quality assessment near a municipal landfill, Lagos, Nigeria. 2(1):39-44.

MacCutcheon SC, Martin JL, Barnwell TO (1983). Water Quality. In Handbook of Hydrology. McGraw-Hill Inc., New York.

Marian E (1991). Metals and their Compounds in the Environment: Occurrence, Analysis and Biological Relevance. UCH, WeinheimNew York-Basel-Cambridge.

Mondal NC, Singh VS, Saxena VK, Prasad RK (2007). Improvement of Groundwater Quality due to Fresh Water Ingress in Potharlanka Island, Krishna Delta, India. Environ Geol.

O'Neil P (1993). Environmental Chemistry. Chapman and Hall, London. p. 193.
Pradhan SK, Patnaik D, Rout SP (2001). Water quality index for the groundwater in and around a phosphatic fertilizer plant. Indian $\mathrm{J}$. Environ. Prot. 21:355-358

Reid DC, Edwards AC, Cooper D, Wilson E, Mcgaw BA (2003). The quality of drinking water from private water supplies in Aberdeenshire, UK. Water Res. 37: 245 - 254.

Singh DSH, Lawrence JF (2007). Groundwater quality assessment of shallow aquifer using geographical information system in part of Chennai city Tamilnadu. J. Geol. Soc. India 69:1067-1076.

Styenberg MC, Venter SN, de Wet CME, du Plessis G, Holos D, Rodda N, Kfir R (1995). Water Science and Technology. Management of Microbial Water Quality: New Perspectives for developing Areas 32(5-6):183-191.

World Health Organization (2004). Guideliness for Drinking-water quality. 1 Recommendations. 3rd Ed. World Health Organization, Geneva.

Woods L (1990). Groundwater quality in the Nore River Bain, Republic of Ireland. M.Sc. dissertation, University College, London. 